\title{
Trading shallow safety for deep sleep: juvenile green turtles select deeper resting sites as they grow
}

\author{
Kristen M. Hart ${ }^{1, *}$, Connor F. White ${ }^{2}$, Autumn R. Iverson $^{3}$, Nick Whitney ${ }^{2}$ \\ ${ }^{1}$ US Geological Survey, Wetland and Aquatic Research Center, 3321 College Avenue, Davie, FL 33314, USA \\ ${ }^{2}$ Behavioral Ecology and Physiology Program, Mote Marine Laboratory, 1600 Ken Thompson Parkway, Sarasota, FL 34236, \\ USA \\ ${ }^{3}$ US Geological Survey (contracted by Cherokee Nation Technologies), Wetland and Aquatic Research Center, \\ 3321 College Avenue, Davie, FL 33314, USA
}

\begin{abstract}
To better protect endangered green sea turtles Chelonia mydas, a more thorough understanding of the behaviors of each life stage is needed. Although dive profile analyses obtained using time-depth loggers have provided some insights into habitat use, recent work has shown that more fine-scale monitoring of body movements is needed to elucidate physical activity patterns. We monitored 11 juvenile green sea turtles with tri-axial acceleration data loggers in their foraging grounds in Dry Tortugas National Park, Florida, USA, for periods ranging from 43 to $118 \mathrm{~h}$ (mean \pm SD: $72.8 \pm 27.3 \mathrm{~h}$ ). Approximately half of the individuals $(\mathrm{n}=5)$ remained in shallow (overall mean depth $<2 \mathrm{~m}$ ) water throughout the experiment, whereas the remaining individuals $(\mathrm{n}=6)$ made excursions to deeper $(4$ to $27 \mathrm{~m})$ waters, often at night. Despite these differences in depth use, acceleration data revealed a consistent pattern of diurnal activity and nocturnal resting in most individuals. Nocturnal depth differences thus do not appear to represent differences in behavior, but rather different strategies to achieve the same behavior: rest. We calculated overall dynamic body acceleration (ODBA) to assess the relative energetic cost of each behavioral strategy in an attempt to explain the differences between them. Animals in deeper water experienced longer resting dives, more time resting per hour, and lower mean hourly ODBA. These results suggest that resting in deeper water provides energetic benefits that outweigh the costs of transiting to deep water and a potential increased risk of predation.
\end{abstract}

KEY WORDS: Chelonia mydas · Dry Tortugas $\cdot$ Accelerometers $\cdot$ Dive profile $\cdot$ Green turtle

\section{INTRODUCTION}

Understanding the movements and behavioral patterns of endangered sea turtles and other marine animals is crucial for determining home ranges and habitat use patterns, and for subsequently designating effective management areas. While the ecology, movements and diving behavior of juvenile green turtles Chelonia mydas have been reasonably well studied (e.g. Makowski et al. 2006, Seminoff et al. 2006, Blumenthal et al. 2010, Thomson et al. 2011, Francke et al. 2013; reviewed in Godley et al. 2008,
Hochscheid 2014), a critical knowledge gap regarding ontogenetic shifts in habitat use patterns for juveniles is currently hindering effective conservation and management strategies (Hazel et al. 2013).

Green sea turtles are found in tropical and subtropical marine habitats around the world (Hirth 1997). They are listed as Endangered by the International Union for the Conservation of Nature (IUCN), while the US Endangered Species Act lists the breeding populations in Florida and the Pacific Coast of Mexico as endangered and all other populations as threatened (NMFS \& USFWS 1991). 
Recently, both US management agencies (i.e. NOAA and USFWS) revealed a proposed rule to change the status of distinct population segments of the species to threatened (Federal Register, March 23, 2015), including green turtles in Florida. As hatchlings leaving the nest, green turtles enter an oceanic phase (Carr \& Meylan 1980, Carr 1987) before recruiting to neritic habitats rich in seagrass or marine algae, where they forage and grow to maturity (Bjorndal 1997, Musick \& Limpus 1997). Although adult green turtles remain largely coastal, they are capable of long distance migrations, with adult females exhibiting philopatry to the region in which they hatched (Allard et al. 1994, Plotkin 2003) and laying several nests over the course of the season (Carr et al. 1974).

Several different techniques have been employed in attempts to observe and study sea turtle behavior. Studies utilizing satellite and acoustic telemetry have inferred specific behaviors from horizontal movement patterns (reviewed in Godley et al. 2008, Hart \& Hyrenbach 2009, and see examples in Hart et al. 2013, Hazel et al. 2013), or from the presence or absence of turtles in certain depths (e.g. Mendonça 1983, Seminoff et al. 2002, McClellan \& Read 2009). Other attempts to examine habitat utilization patterns have used depth-sensing acoustic transmitters or time-depth recorders (TDRs), sometimes coupled with satellite telemetry, to provide dive profiles from which behaviors can be extrapolated (e.g. Brill et al. 1995, Minamikawa et al. 1997, Houghton et al. 2002, Southwood et al. 2003, Makowski et al. 2006, Blumenthal et al. 2010, reviewed in Hochscheid 2014). For example, short dives with continuous depth fluctuations at the bottom of the dive have been assumed to represent foraging (e.g. Brill et al. 1995, van Dam \& Diez 1996, Makowski et al. 2006, Seminoff et al. 2006), whereas long dives to a fixed depth are often thought to represent resting (Hays et al. 2000, 2001, Blumenthal et al. 2010, Okuyama et al. 2013). Recent studies using TDRs in conjunction with video observations have shown that resting and foraging can occur at multiple depths (Seminoff et al. 2006), and that the maximum depth of dives did not necessarily correspond with seafloor depth (Thomson et al. 2011). Additionally, while Francke et al. (2013) found behaviors such as foraging, hovering, and breathing could be determined by specific TDR parameters, other behaviors such as swimming and resting could not. From these studies, it is clear that a thorough understanding of turtle behavior during dives is dependent on the ability to obtain more fine-scale movement data.
Acceleration data loggers (accelerometers) are relatively novel tools that have become popular for studying fine-scale movements and elucidating animal behavioral patterns. These loggers measure multi-dimensional acceleration, providing precise information on an animal's movements and body orientation, as well as depth and temperature. When combined, these complementary data can reveal behaviors, activity level, and energy expenditure (Gleiss et al. 2010, Okuyama et al. 2014). Accelerometers have been proven effective in studies on sea turtle feeding (Okuyama et al. 2010), respiratory behavior (Okuyama et al. 2014), and for quantifying diving behavior (Fossette et al. 2010), swimming speeds, and rates of energy expenditure (Yasuda \& Arai 2009, Halsey et al. 2011, Okuyama et al. 2012, 2014).

In this study, we deployed tri-axial accelerometers on juvenile green turtles in an undisturbed shallow nursery area in Dry Tortugas National Park, Florida (DRTO), to obtain fine-scale measurements of behavior, activity patterns, and associated dive profiles for juveniles of this species. The goals of the study were to (1) describe the fine-scale behavior and time budgets of juvenile green turtles in a nursery habitat, (2) document the relative activity of animals over the course of multiple diel cycles, and (3) use that information to shed light on the physiological constraints that may dictate turtle behavior and vertical habitat selection.

\section{MATERIALS AND METHODS}

\section{Study site}

We deployed accelerometers on juvenile green turtles caught in Dry Tortugas National Park, a cluster of islands approximately $100 \mathrm{~km}$ west of Key West, FL (near $24^{\circ} 38^{\prime} 00^{\prime \prime} \mathrm{N}, 82^{\circ} 55^{\prime} 12^{\prime \prime} \mathrm{W}$ ) in the US Gulf of Mexico (Fig. 1). The region was designated a Wildlife Refuge in 1908, a National Monument in 1935, and a National Park in 1992. The Dry Tortugas consists of a series of carbonate banks and sand shoals in which the banks roughly form a circular pattern resembling an atoll (Mallinson et al. 2003). In January 2007, 74 $\mathrm{km}^{2}$ of the park were designated a Research Natural Area (RNA), creating a no-take preserve to foster ecological self-renewal by minimizing anthropogenic influences (National Park Service 2006). The RNA complements the adjacent Tortugas Ecological Reserve of the Florida Keys National Marine Sanctuary, established by the National Oceanic and Atmos- 

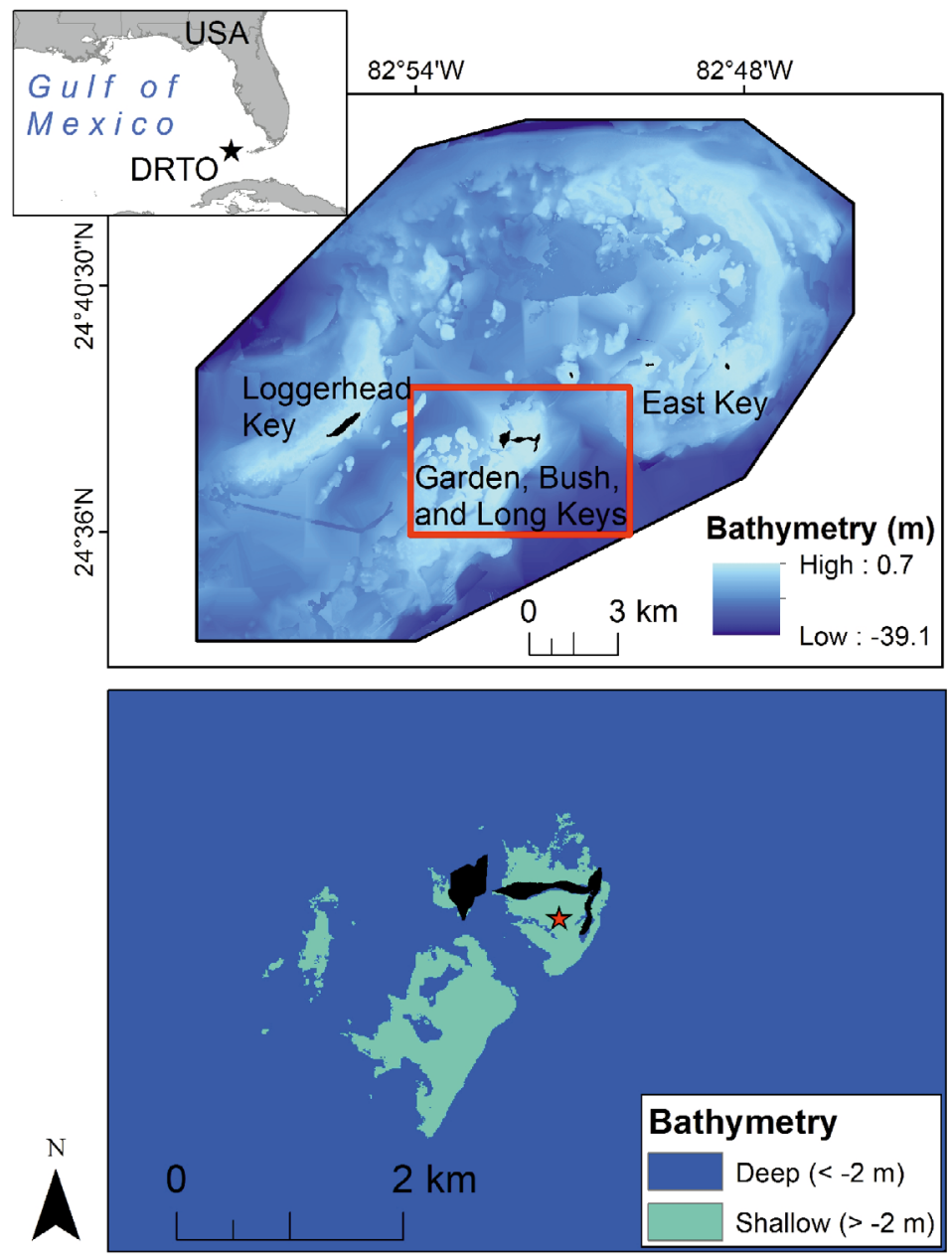

Fig. 1. Bathymetric map of the study site in Dry Tortugas National Park, Florida (DRTO). Red star in bottom panel: general capture area of green sea turtles Chelonia mydas

pheric Administration (NOAA) and the State of Florida. An area of shallow flats partially enclosed by Bush and Long Keys provides habitat for sea grasses and various marine invertebrates as well as various fish species (Carrier \& Pratt 1998, Zawada \& Hart 2010). This area represents a truly undisturbed developmental habitat for juvenile green turtles, and has allowed researchers to examine the natural behavior of these endangered animals in the past, capturing and tagging them with a mean recapture rate of $65.2 \%$ over 17 sampling trips between 2008 and 2015 (K. M. Hart unpubl. data).

\section{Animal capture and data logger attachment}

We captured turtles using dip nets during the day while aboard a $4.3 \mathrm{~m}$ Livingston skiff equipped with a $25 \mathrm{hp}$ motor, a capture method shown to be safe for juvenile turtles (Schmid 1998, Ehrhart \& Ogren 1999, Hart \& Fujisaki 2010). We determined recapture status (recapture or new) by scanning for passive integrated transponder (PIT) tags. For newly captured turtles, we marked each animal by inserting a PIT tag in the right shoulder and affixing individually numbered flipper tags to each of the front flippers following established protocols (NMFS-SEFSC 2008). Immediately after marking each animal or confirming that it was a recapture, we took standard measurements including curved (CCL) and straight (SCL) carapace lengths. We weighed all turtles with a spring scale and netting, estimating mass to the nearest $0.1 \mathrm{~kg}$, and documented carapace and skin anomalies.

Prior to tag attachment, we removed epibionts from the attachment site (highest vertebral section of anterior carapace), and cleaned the site with $91 \%$ isopropyl alcohol. We lightly sanded the site, cleaned it again with isopropyl alcohol, and allowed it to dry before attaching the loggers using Superbond $^{\mathrm{TM}}$ epoxy (a 2-part cool-setting epoxy). We tagged turtles with Cefas G6a accelerometer data loggers programmed to sample tri-axial acceleration at $25 \mathrm{~Hz}$, depth at $1 \mathrm{~Hz}$, and temperature $\left(0.031^{\circ} \mathrm{C}\right.$ resolution) once every $30 \mathrm{~s}$. These devices were $40 \times 28 \times$ $16.3 \mathrm{~mm}$ and weighed $18.6 \mathrm{~g}$ in air. Depth sensor resolution was $4 \mathrm{~cm}$, and range of acceleration measured was $\pm 2 \mathrm{~g}$ with a resolution of $0.001 \mathrm{~g}$. We also tagged 3 of the turtles with a MM110 VHF tag $(13 \times 35 \mathrm{~mm}, 10 \mathrm{~g}$; Advanced Telemetry Systems), and 5 with a V16-5H acoustic transmitter $(16 \times 95 \mathrm{~mm}, 36 \mathrm{~g}$ i Vemco Amirix) to facilitate active tracking and assist with recapture and logger removal. Total tag weight on each turtle represented $<2 \%$ of the animal's body weight, as typically recommended for tagging studies. After allowing the tag epoxy to dry for $45 \mathrm{~min}$, we released each turtle at the site of capture.

We attempted direct behavioral observations but were largely unsuccessful due to animal sensitivity to humans and poor underwater visibility due to silt and excrement from the local tern colony. However, spontaneous validation of animal location and habitat type was possible for animals equipped with acoustic or VHF transmitters, and the latter also provided validation of surfacing behaviors.

To recover the data loggers, we located tagged animals using a VHF or acoustic receiver and attempted 
recapture using the same dip-net method described above. Animals equipped only with data loggers were recaptured when observed on several trips specifically looking for tagged individuals. Once recaptured, we removed the data loggers and released turtles at the site of recapture.

\section{Acceleration data processing}

After we downloaded the data loggers, we imported the data into Igor Pro v.6.22 (WaveMetrics) and conducted analyses using Ethographer (Sakamoto et al. 2009). To account for depth sensor drift, we standardized depth by the minimum depth each hour, which was assumed to represent the surface.

To eliminate surface turbulence from our depth and acceleration data, as well as to standardize data for comparisons across individuals and time frames, we broke our continuous traces into discrete dives. Other studies have used varying criteria to define dives (e.g. depth $>1.5 \mathrm{~m}$, or starting when the rate of descent was $>0.3 \mathrm{~m} \mathrm{~s}^{-1}$ and ending when both the rate of ascent was $>0.3 \mathrm{~m} \mathrm{~s}^{-1}$ and the depth was $<10 \%$ of the maximum for that dive) (Hays et al. 2001, Cheng et al. 2013, reviewed in Hochscheid 2014); however, the extremely shallow nature of our study site precluded our use of these established definitions. We therefore classified dives as periods when the animal was below $0.25 \mathrm{~m}$ for at least $30 \mathrm{~s}$.

We derived dynamic acceleration using a continuous wavelet transformation low pass filter with a periodicity between 0.5 and $5 \mathrm{~s}$, with the derived flipper beat acceleration amplitude (FBAA) and flipper beat frequency (FBF) calculated every second from a spectrum analysis on the heave axis. We used $k$ means clustering (Sakamoto et al. 2009) to create 5 behavioral categories based on FBAA and FBF. By examining the $k$-means clusters we were able to visually interpret and assign one of the groups as resting. Overall dynamic body acceleration (ODBA) was calculated by summing the absolute value of the sway, surge, and heave axes every second (Wilson et al. 2008).

We classified a dive as a 'resting dive' if $>50 \%$ of the dive was determined to be resting behavior, as determined through the $k$-means clustering, while all other dives were classified as 'active dives'. Dives were further classified as deep if the maximum dive depth was $>2 \mathrm{~m}$, as this corresponds to habitats outside of the flats; all other dives were considered shallow. We also classified a sub-set of active dives as transiting periods, defined as episodes of movement between shallow and deeper habitats. These periods were visually identified as a series of dives between a shallow active period and a deep resting period. When transiting was from shallow to deep water, the transiting period was delimited using the first dive to a depth below $2 \mathrm{~m}$ as the start of the transiting period, and the last active dive before a period of deep resting as the end of the transiting period. When transiting was from deep to shallow, transiting was considered to begin on the first active dive after deep resting, and to end after the last dive deeper than $2 \mathrm{~m}$. To separate nighttime and daytime dives and behaviors, we used sunrise and sunset data for Garden Key, Dry Tortugas, Florida as provided by the WWW Tide and Current Predictor (Biological Sciences, University of South Carolina; http://tbone. biol.sc.edu/tide). During times when data loggers were on turtles, there was little variability in sunrise times (06:49 to $07: 19 \mathrm{~h}$ ) or sunset times (19:29 to $20: 23 \mathrm{~h})$.

\section{Statistical analysis}

We used R v.2.15.2 (R Core Team 2016) for statistical analysis. Each dive was considered a single data point, and variables were log transformed in order to reduce heteroscedasticity and improve model fit. Due to the repeated measure nature of our data, with multiple dives being recorded for a single individual, we treated individual as a random term using mixed modeling procedures from the 'nlme' package in $\mathrm{R}$ (Pinheiro et al. 2014). The duration of a turtle's dive is dependent on both the size of a breath taken at the surface and the energy expenditure during a dive. The size of the breath can also influence turtle dive depth as it impacts the depth of neutral buoyancy (Hays et al. 2004); turtles modulate the size of their breath based on the intent of the dive (Okuyama et al. 2014). Accordingly, we modeled the effect of dive depth and activity level (i.e. ODBA) on the duration of a dive (Okuyama et al. 2012).

In order to investigate the diel and depth patterns observed in the diving behaviors of turtles, we calculated hourly means for each turtle for the following metrics: time resting, time diving, average ODBA, average depth, average dive depth, average dive duration, and percent of dive resting. We then tested each factor for diel variation using mixed models with a categorical predictor of day/night, and another of deep/shallow (with a $2 \mathrm{~m}$ cutoff) determined by maximum dive depth of that hour. 
Table 1. Animal size and tagging information for juvenile green sea turtles Chelonia mydas tagged with Cefas G6a accelerometers for this study. All depth and duration values are represented as mean \pm SD. CCL: curved carapace length

\begin{tabular}{|c|c|c|c|c|c|c|c|c|}
\hline \multirow[t]{2}{*}{ Turtle } & \multirow[t]{2}{*}{ Date tagged } & \multirow{2}{*}{$\begin{array}{l}\text { CCL } \\
(\mathrm{cm})\end{array}$} & \multirow{2}{*}{$\begin{array}{l}\text { Weight } \\
(\mathrm{kg})\end{array}$} & \multirow{2}{*}{$\begin{array}{l}\text { Recording } \\
\text { period (h) }\end{array}$} & \multirow{2}{*}{$\begin{array}{l}\text { Day dive } \\
\text { depth }(\mathrm{m})\end{array}$} & \multirow{2}{*}{$\begin{array}{l}\text { Night dive } \\
\text { depth }(m)\end{array}$} & \multicolumn{2}{|c|}{ Day duration (min) } \\
\hline & & & & & & & Day & Night \\
\hline T1 & 20-Sep-2010 & 45.9 & 10.4 & 46 & $2.93 \pm 4.98$ & $0.31 \pm 0.11$ & $419.45 \pm 536.80$ & $34.68 \pm 53.28$ \\
\hline $\mathrm{T} 2^{\mathrm{a}, \mathrm{b}}$ & 20-Sep-2010 & 59.7 & 21.8 & 43 & $1.24 \pm 1.68$ & $0.28 \pm 0.01$ & $287.05 \pm 399.16$ & $56.29 \pm 26.90$ \\
\hline T3 & 5-Мау-2012 & 42 & 10.2 & 102 & $1.64 \pm 2.71$ & $8.78 \pm 3.05$ & $176.93 \pm 226.36$ & $1129.36 \pm 485.71$ \\
\hline $\mathrm{T} 4^{\mathrm{a}}$ & 10-May-2012 & 40.7 & 8.4 & 118 & $0.82 \pm 0.28$ & $0.41 \pm 0.20$ & $167.38 \pm 110.47$ & $160.69 \pm 169.41$ \\
\hline T5 & 7-Jul-2012 & 43.1 & 9.9 & 94 & $2.24 \pm 4.03$ & $12.48 \pm 2.46$ & $258.24 \pm 418.24$ & $1970.47 \pm 428.74$ \\
\hline $\mathrm{T} 6^{\mathrm{a}}$ & 7-Jul-2012 & 30.6 & 3.6 & 71 & $0.56 \pm 0.16$ & $0.80 \pm 0.40$ & $110.06 \pm 89.17$ & $377.78 \pm 224.64$ \\
\hline $\mathrm{T} 7^{\mathrm{a}}$ & 7-Jul-2012 & 39.1 & 5.8 & 72 & $0.70 \pm 0.33$ & $0.80 \pm 0.27$ & $167.19 \pm 114.42$ & $393.78 \pm 190.79$ \\
\hline T8 & 7-Jul-2012 & 44.1 & 8.8 & 90 & $1.66 \pm 1.75$ & $2.70 \pm 1.77$ & $279.76 \pm 250.43$ & $659.19 \pm 282.99$ \\
\hline $\mathrm{T}^{\mathrm{a}}$ & 8-Jul-2012 & 35.3 & 4.8 & 47 & $0.63 \pm 0.22$ & $0.56 \pm 0.13$ & $118.00 \pm 99.05$ & $321.28 \pm 147.99$ \\
\hline T10 & 8-Jul-2012 & 33.3 & 3.8 & 46 & $1.70 \pm 1.31$ & $3.48 \pm 0.33$ & $225.06 \pm 225.57$ & $758.04 \pm 198.51$ \\
\hline \multirow[t]{2}{*}{$\mathrm{T} 11^{\mathrm{a}}$} & 8-Jul-2012 & 38.4 & 6.2 & 46 & $0.59 \pm 0.23$ & $0.45 \pm 0.23$ & $100.44 \pm 73.37$ & $102.42 \pm 71.12$ \\
\hline & Mean $\pm \mathrm{SD}$ & $41.1 \pm 7.7$ & & & & & & \\
\hline
\end{tabular}

\section{RESULTS}

We tagged 2 juvenile green turtles in September 2010, 2 in May 2012, and 8 in July 2012. Turtles ranged in size from 30.6 to $59.7 \mathrm{~cm}$ CCL (mean \pm SD: $41.1 \pm 7.7 \mathrm{~cm}$ ) (Table 1). We recovered data loggers from 11 of the 12 turtles for a total of $751 \mathrm{~h}$ of data, with a mean record duration of $68.3 \pm 33.3 \mathrm{~h}$ turtle $^{-1}$ (range: 43 to $118 \mathrm{~h}$ ) (Table 1). One logger failed to record accurate acceleration data and could therefore only be used in depth and temperature analyses. We recorded a total of 9205 dives, with each turtle logging between 198 and 1422 dives (mean \pm SD: $11.75 \pm 5.14$ dives $\mathrm{h}^{-1}$ ). The mean depth of all dives in the study was $1.34 \pm 2.33 \mathrm{~m}$, and overall mean duration was $234 \pm 314 \mathrm{~s}$. The maximum dive depth for each individual ranged from 3.5 to $27.0 \mathrm{~m}$. Most turtles spent a great deal of time in shallow water, with 6 of 11 animals maintaining mean depths $<1 \mathrm{~m}$ for multiple consecutive days (Table 1, Fig. 2). We divided the turtles into a 'shallow' group and a 'deep' group, determined using a $2 \mathrm{~m}$ mean depth cutoff point. Animals that did make deeper dives typically did so at night (Fig. 2). Temperatures experienced by tagged turtles were similar, with the mean temperatures for each turtle ranging from 27.5 to $29.9^{\circ} \mathrm{C}$. We found no significant differences in temperature between 'deep' and 'shallow' dives, and no significant correlations between temperature and any of our hourly dive metrics.

Animals that made deep forays were generally larger than those that remained in the shallows throughout the monitoring period (Fig. 3). The one exception to this pattern was the largest turtle (T2; Table 1), a $59.7 \mathrm{~cm}$ CCL animal with a missing rear right flipper. Limiting analysis to fully intact animals ( $\mathrm{n}=10)$, maximum depth obtained for each turtle correlated significantly with CCL $\left(\rho=0.68, t_{1,8}=2.63\right.$, $\mathrm{p}=0.030$; Fig. 3 ) and weight $\left(\rho=0.84, t_{1,8}=4.37, \mathrm{p}=\right.$ 0.002). Additionally, when limiting analyses to only resting dives, maximum resting depth correlated significantly with weight $\left(\rho=0.84, t_{1,7}=3.59, \mathrm{p}=0.009\right.$ ) but not CCL $\left(\rho=0.62, t_{1,7}=2.13, p=0.071\right)$

The $k$-means clustering of body acceleration data resulted in 5 unique behavioral clusters. One of these appeared to be representative of a single unique behavior: resting, characterized by a lack of consistent flipper beats and low acceleration amplitude (Fig. 4b,d). Using $k$-means clusters and depth data, we determined 5 broad categories of behavior: 'shallow active', 'shallow rest', 'deep active', 'deep rest', and 'transiting' (a sub-category representative of dives moving between shallow and deeper water habitats) (Fig. 4). Shallow active was the most common behavior in terms of both percent time and number of individuals exhibiting it. This was followed by shallow rest, deep rest, deep active, and transiting (Table 2, Fig. 4).

Accelerometer data revealed that behaviors had significantly different average ODBA per dive $\left(F_{2,9001.3}=4146, \mathrm{p}<0.001\right)($ Table 2$)$. The increased ODBA correlates with increased energy expenditure (Halsey et al. 2011) and thus, in the case of transiting behavior, equates to an increased cost of moving from shallow environments to deeper ones. Transiting was not a particularly common behavior, accounting for 


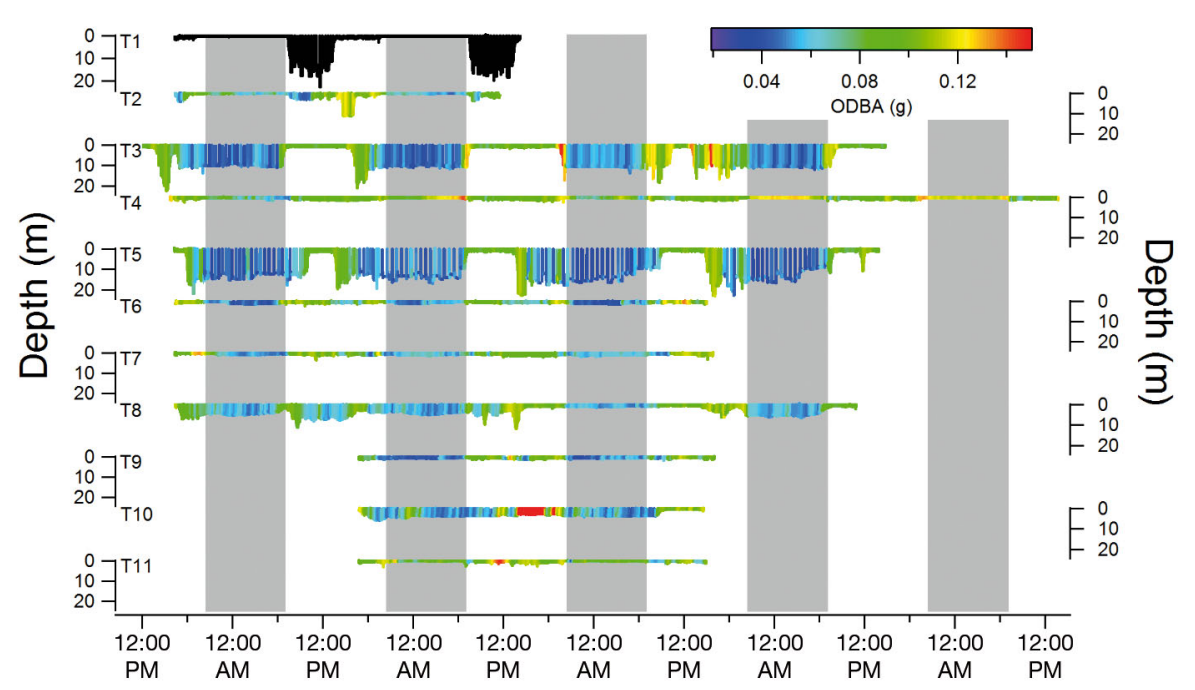

Fig. 2. Depth traces for all green sea turtles Chelonia mydas, color-coded by overall dynamic body acceleration (ODBA) each second. Blue and purple shades are representative of resting behaviors, while greens, yellows, and reds are representative of increasingly active dives. Gray bars represent nighttime. T1 is not colored for ODBA as the acceleration sensors failed for this tag

only $2.9 \%$ of dive times (Table 2). Haphazard direct observations indicated that 'shallow active' animals were likely feeding in shallow areas dominated by turtle grass Thalassia testudinum and manatee grass Syringodium filiforme as well as loggerhead barrel sponges Spheciospongia vesparium (habitat described by Lidz \& Zawada 2013).

Each turtle's maximum dive depth was found to significantly correlate with their maximum dive duration ( $\left.\rho=0.72, t_{1,9}=3.11, p=0.012\right)$. When analyzed for individual dives, average ODBA and dive depth were found to significantly predict $69.2 \%$ in the variation of dive duration (Fig. 5). Dives with deeper and lower activity levels lasted significantly longer $\left(\mathrm{ODBA}: F_{1,9001}=6395, \mathrm{p}<0.001\right.$; dive depth:
$\left.F_{1,8961}=7274, \mathrm{p}<0.001\right)$ whereas the largest proportion of dives were 'shallow active' and showed a broad range of activity levels (Fig. 5).

\section{Nocturnal resting}

Although some animals remained shallow at night and others ventured deeper, acceleration data revealed that nearly all animals exhibited a pattern of diurnal activity and nocturnal resting (Fig. 2). Overall, turtles spent $72.7 \pm 5.2 \%$ of their time active during the day and only $38.9 \pm 19.9 \%$ of their time active at night $(F=794.49$, p $<0.001$; Fig. 6). Additionally, mean hourly ODBA was higher during the

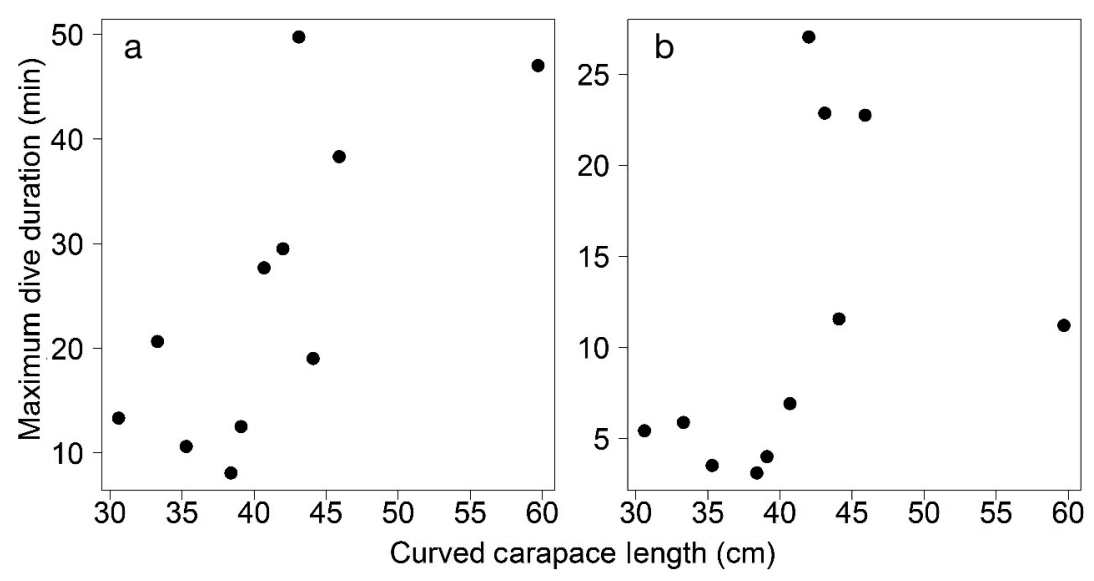

Fig. 3. (a) Maximum dive depth and (b) maximum dive duration versus curved carapace length of green sea turtles Chelonia mydas 

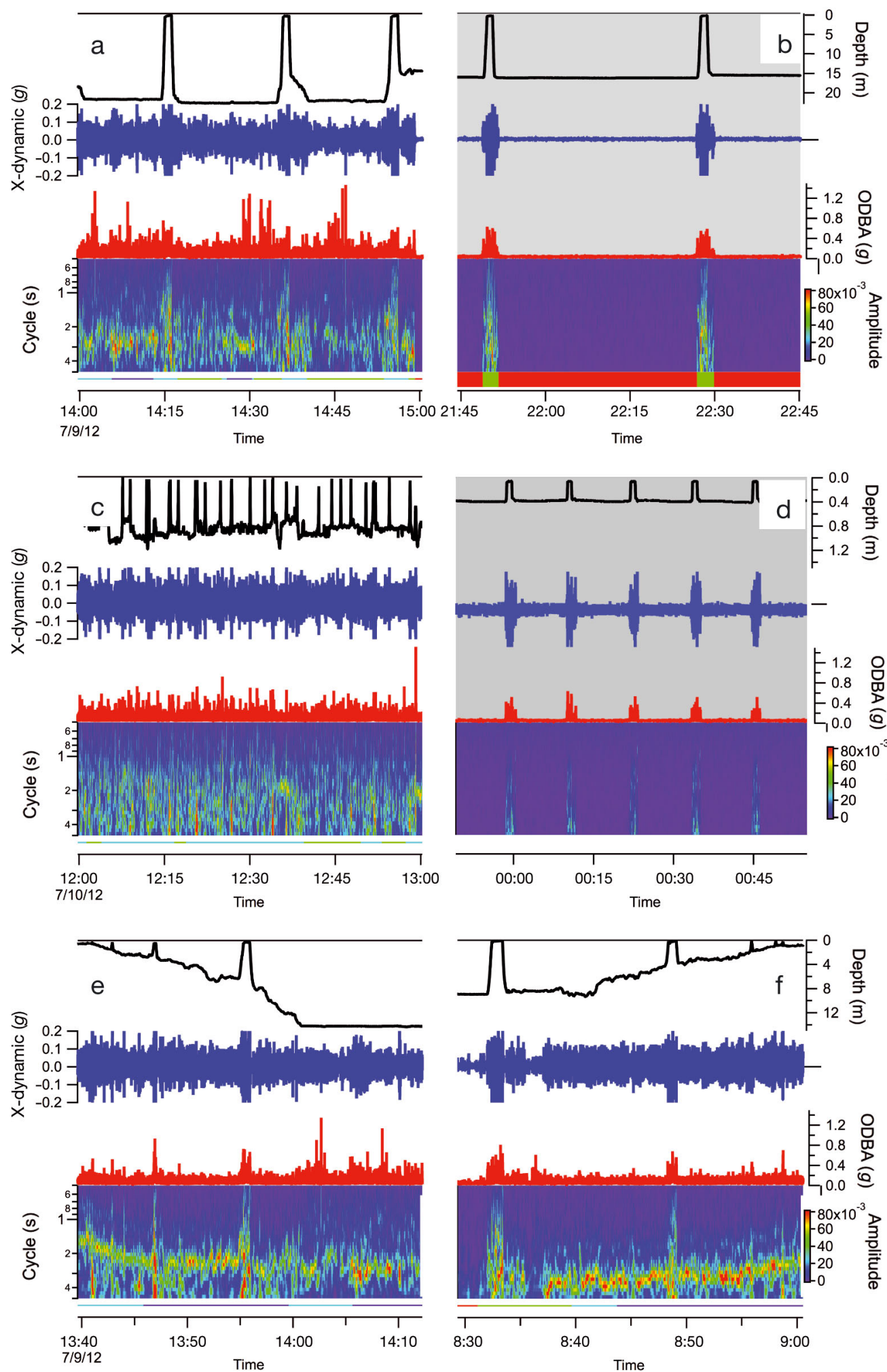

Fig. 4. Examples of each of the 6 behaviors of green sea turtles Chelonia mydas observed during our study: (a) deep active, (b) deep rest, (c) shallow active, (d) shallow rest, (e) transiting from shallow to deep waters, (f) transiting from deep to shallow waters. X-dynamic: dynamic acceleration of flipper beats (in $g$ ); ODBA: overall dynamic body acceleration (in $g$ ); cycle: flipper beat cycle (in s; typically between 2 and $4 \mathrm{~s} \mathrm{cycle}^{-1}$ ); amplitude: a measure of flipper beat signal strength amplitude (unitless). 
Table 2. Characteristics of the dive behavior classifications of green sea turtles Chelonia mydas calculated from $k$-means clustering and dive depth, including the percent time spent on each activity in day versus night. Data are only included from animals for which acceleration data was obtained $(n=10)$. FBF: flipper beat frequency; FBAA: flipper beat acceleration amplitude; ODBA: overall dynamic body acceleration. All FBF, FBAA, and ODBA values are presented as mean \pm SD

\begin{tabular}{|lccccrrr|r|}
\hline Behavior & $\begin{array}{c}\text { No. of } \\
\text { individuals }\end{array}$ & $\begin{array}{c}\text { No. of } \\
\text { dives }\end{array}$ & $\begin{array}{l}\text { FBF } \\
(\mathrm{Hz})\end{array}$ & $\begin{array}{c}\text { FBAA } \\
(g)\end{array}$ & $\begin{array}{c}\text { ODBA } \\
(g)\end{array}$ & $\begin{array}{r}\text { Percent of } \\
\text { daytime }\end{array}$ & $\begin{array}{r}\text { Percent of } \\
\text { nighttime }\end{array}$ \\
\hline Shallow active & 10 & 4128 & $0.370 \pm 0.076$ & $0.047 \pm 0.016$ & $0.097 \pm 0.021$ & 55.44 & 6.59 \\
Shallow rest & 9 & 1195 & $0.406 \pm 0.146$ & $0.015 \pm 0.006$ & $0.049 \pm 0.013$ & 11.13 & 35.91 \\
Deep active & 8 & 228 & $0.344 \pm 0.031$ & $0.054 \pm 0.017$ & $0.112 \pm 0.027$ & 9.61 & 2.75 \\
$\begin{array}{l}\text { Deep rest } \\
\text { Transiting }\end{array}$ & 8 & 550 & $0.480 \pm 0.138$ & $0.013 \pm 0.006$ & $0.048 \pm 0.010$ & 14.00 & 53.22 \\
\end{tabular}

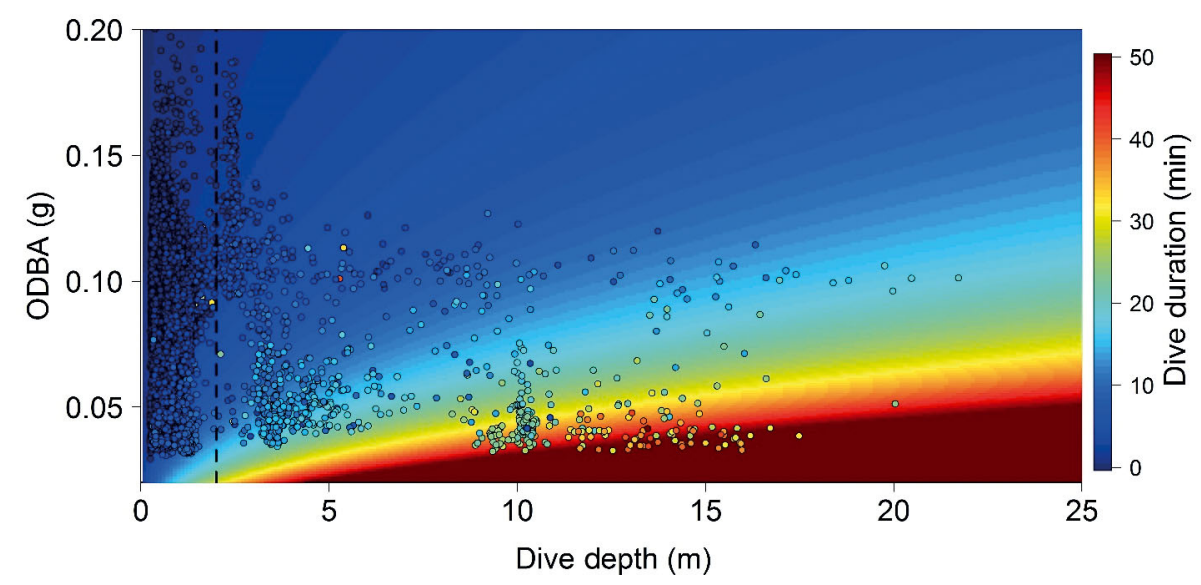

Fig. 5. Overall dynamic body acceleration (ODBA) versus dive depth in green sea turtles Chelonia mydas, color coded by dive duration for all dives. Color shading represents results of a model constructed to predict dive duration based on dive depth and ODBA. Dashed line: the $2 \mathrm{~m}$ depth cutoff used for analyses comparing 'shallow' vs. 'deep'

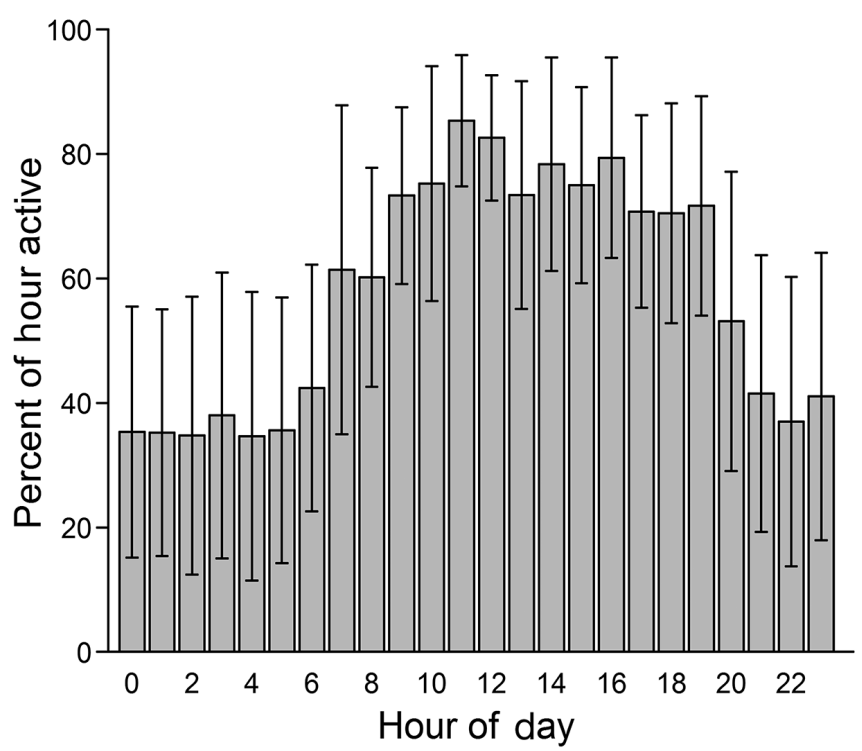

Fig. 6. Percent of each hour spent active (mean $\pm \mathrm{SD}$ ) throughout the diel cycle for green sea turtles Chelonia mydas day than at night $(F=296.96, \mathrm{p}<0.001)$. Several exceptions can be noted in T4 and T11 (Fig. 2); these 2 turtles exhibited multiple nights of high activity in the shallows.

Although there were no significant differences in active behaviors between shallow and deep water, resting in deeper water differed from shallow water resting in several ways. Turtles resting in deeper water at night spent more time resting per hour $(\mathrm{p}<$ $0.001)$, showed lower mean hourly ODBA $(p<0.001)$, exhibited lower average ODBA $(\mathrm{p}<0.001)$, spent a higher percentage of each dive resting $(p<0.001)$, and had longer resting bout duration $(p<0.001)$ than animals resting in shallow water (Fig. 7). Two of the 3 animals equipped with VHF transmitters were detected resting at night in water shallow enough to allow their $25 \mathrm{~cm}$ VHF antennas to remain above the surface continuously for periods $>1 \mathrm{~h}$. One of these animals (T2) was approached on foot and found to be resting in the extreme shallows ( $<15 \mathrm{~cm}$ water depth) so that it did not have to swim to the surface to breathe, but merely lifted its head above the surface. 


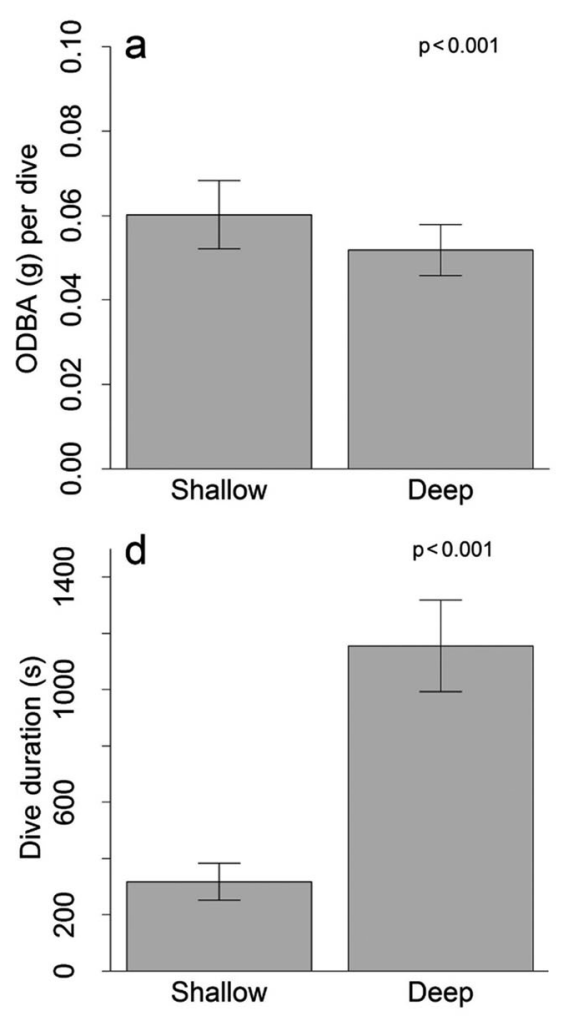

\section{DISCUSSION}

Juvenile green sea turtles in DRTO utilized extremely shallow foraging grounds with occasional forays into deeper water in a pattern that has been documented for this species in other areas (Southwood et al. 2003, Makowski et al. 2006, Blumenthal et al. 2010, Okuyama et al. 2013) and for juveniles of other hardshell species (Blumenthal et al. 2009). Accelerometers allowed us to quantify activity levels and determine that juvenile green turtles spend much of their time resting during deeper excursions. These deep forays typically occurred at nighttime, when individuals remaining in the shallows also rested.

While it has long been known that adult green turtles utilize deeper water than juveniles (Bolten 2003), the proximate driver of this change in habitat remains unknown. Seminoff \& Jones (2006) proposed that the deeper nocturnal dives observed in green turtles in Baja California were spent foraging or resting; however, they had no way of determining these specific behaviors. Here, acceleration data revealed that the majority of deep dives seen in our study site were spent resting. This is supported by a consistent availability of plant matter and other potential prey items at all depths observed here, suggesting that deeper waters are not being selected for improved foraging success. Thus, pursuit of better foraging grounds is also not supported by the activity traces of the deeper diving animals, nor by our knowledge of the deeper habitats (Lidz \& Zawada 2013, K. M. Hart pers. obs.).

We propose that deeper nocturnal resting affords animals an energetic advantage over animals that remain in shallows. Rest and minimizing energy expenditure is particularly important in juveniles, as energy is needed for somatic growth (Okuyama et al. 2013). Animals choosing to rest in deeper waters likely experienced significant energetic advantages, evidenced by more time spent resting per hour, lower hourly ODBA, and longer resting bouts. As an airbreathing animal descends below the surface, the volume of air in the lungs decreases due to increased pressure, and the animal's buoyancy is thereby reduced until it reaches a depth at which it goes from positive to neutral or negative buoyancy (Hays et al. 2004). The larger the breath taken at the surface, the deeper the point of neutral buoyancy, and the greater oxygen stores the animal has available during the dive (Hochscheid et al. 1999, 2003, Hays et al. 2004). Therefore, as turtles grow larger, they will actively seek out waters in which they are able to achieve neutral buoyancy, and lengthen their resting dives to achieve maximum benefit from resting behaviors. This supports the trend observed here for larger turtles to rest longer and deeper. Our results also align with findings from Blumenthal et al. (2009), who 
found that juvenile hawksbill turtles Eretmochelys imbricata began resting in deeper water as their weight approached $10 \mathrm{~kg}$, which is a similar cutoff to that for the juvenile green turtles studied here (Fig. 3). Blumenthal et al. (2010) also found variability in maximum dive depth between individual green turtles. However, all of the turtles in their study went $>10 \mathrm{~m}$ at least once, while over half of the turtles in our study never reached this depth. This may be due to the fact that most of the animals we studied were $<45 \mathrm{~cm}$ CCL, whereas the turtles studied by Blumenthal et al. (2010) were mostly in the 50 to $60 \mathrm{~cm}$ CCL range. No turtle in our study smaller than $41 \mathrm{~cm}$ CCL was observed to dive below $10 \mathrm{~m}$, while all turtles larger than this size were observed to dive deep at least once. This indicates that at approximately $40 \mathrm{~cm}$ CCL (mass: 8.4 to $10.4 \mathrm{~kg}$ ) juvenile green turtles in this population appear to go through an ontogenetic shift and begin to partially utilize deeper habitats. This threshold may represent the maximize size at which turtles can stay negatively buoyant in shallow waters with a full breath of air. Above this size, turtles may need to seek deeper water where increased pressure will allow them to achieve negative buoyancy while still taking a full breath of air, and thereby allow them to maximize dive duration and resting bout efficiency, as indicated by our metrics.

These benefits of resting in deep water are apparently great enough to outweigh increased costs and risks associated with this behavior. We found transiting behavior had significantly higher ODBA values than other active behaviors, meaning it is likely energetically costly. Time spent transiting was relatively brief compared to other activities, but this cost may have been high enough to prevent some of the smaller individuals from exhibiting deep water resting. Energetic and time costs are major factors in determining whether an animal undertakes longdistance migrations (Alerstam et al. 2003), and likely also influence short-term movements such as the diel patterns observed here.

Additionally, transiting to a separate resting site and the longer surfacing intervals necessary while resting in deep water (Okuyama et al. 2013) likely expose turtles to a higher predation risk than that of shallow-water resting, particularly at night when visibility is reduced. The authors have noticed an abundance of scarring or predation-related wounds on juvenile turtles in DRTO (16/80 [20\%] individuals with injury, including 7 major e.g. missing flippers, shark bite, large scars/wounds) (K. M. Hart unpubl. data), and large predatory sharks (e.g. tiger shark Galeocerdo cuvier; Ault et al. 2008), goliath grouper Epi- nephelus itajara, and an American crocodile Crocodylus acutus have been observed in the area (Ault et al. 2013), suggesting that predation risk may be influencing the habitat utilization patterns of these juvenile turtles. Large predatory sharks and teleosts are commonly seen in the surrounding, deeper areas, but are not typically seen in the shallow ( 1 $\mathrm{m}$ water depth) grass flat where these turtles were observed, captured, and recaptured (authors' unpubl. data). Although little is known about predation rates for juvenile sea turtles (see Bjorndal et al. 2003), or how relative risk of predation affects their behavior, Heithaus et al. (2002, 2007) found adult green turtles were safer in waters 6 to $12 \mathrm{~m}$ compared to waters $<4 \mathrm{~m}$ deep. The high predation rates observed in Shark Bay, Australia were attributed to the ability of tiger sharks to ambush turtles in several meters of water (Heithaus et al. 2002, 2007). However, the results presented here are focused on a different life stage and a shallower depth range. At our study site in DRTO, turtles spent much of their shallow resting time in $1 \mathrm{~m}$ of water or less which is likely too shallow for potential predators, meaning shallow resting would incur minimal predation risk. A small animal transiting out of a core refuge and foraging area may also risk getting lost or failing to return to the core area, which could be yet another incentive to remain in the shallows.

Our findings support those of previous studies indicating that depth profiles alone are not sufficient for predicting behavior or even activity level of diving sea turtles (e.g. Hochscheid et al. 1999, Seminoff et al. 2006, Thomson et al. 2011, Hochscheid 2014). Using ODBA, we made direct measurements instead of relying upon assumptions concerning activity levels. Although we cannot say definitively that all dives in which animals were active during the bottom phase were foraging dives, our distinct measure of body movement and spontaneous visual observations led us to believe that feeding was likely, particularly for the most common 'shallow active' dive type. Additionally, we were able to use ODBA (a proxy for activity) to help predict dive duration, as shown by Okuyama et al. (2012). Further examination of this relationship may provide insight into energy conservation strategies or underlying mechanisms for species-specific life history traits.

Our data do not indicate bimodal peaks in foraging activity during the day as has been noted in some previous studies (Bjorndal 1980, Mendonça 1983, Ogden et al. 1983, Okuyama et al. 2013) but are more consistent with other green turtle studies citing an overall period of daytime foraging, often peaking mid-day (e.g. Williams 1988, Makowski et al. 2006, MacDonald 
et al. 2013). This is corroborated by results from a study involving lavage sampling of green turtles in DRTO, which found many turtles had eaten seagrass during the day (K.M. Hart unpubl. data). Bjorndal (1980) reported anecdotal observations of green turtles feeding on 'bright, moonlit nights' and Taquet et al. (2006) noted that turtle presence in the seagrass foraging area was positively correlated with an ambient light index. Although 2 turtles in our study exhibited multiple nights of high activity levels in the shallows likely associated with foraging, these animals were not tagged during the same period, and other animals carrying tags at the same time showed resting behavior on these nights. Thus, nocturnal foraging activity appears to be associated with individual variability rather than any environmental factors.

Several studies have attempted to look at underlying causes of animal movements and migrations, and have tested the hypothesis that migrating individuals behave in a way that minimizes the risk of predation mortality while increasing growth rate (Werner \& Gilliam 1984, Brönmark et al. 2008, Chapman et al. 2011, Skov et al. 2011). Although these studies emphasize the impact of energetic gains on growth rate resulting from foraging, rest is also an important factor in somatic growth (Okuyama et al. 2013). Indeed, resting can result in net energetic benefits equal to continuous foraging (Enright 1977). The energetic benefits of deep water resting described here (e.g. more time resting per hour, lower hourly ODBA, and longer resting bouts), appear to be great enough that individuals are willing to tolerate increased energy expenditure during transiting, as well as increased risk of predation and getting lost in order to maximize energy savings during rest.

Acknowledgements. This work was completed under permits NMFS 13307-03 and NPS DRTO-2010- SCI-0009, and adhered to Animal Care Protocols USGS-SESC-IACUC 2011-05. Funding was provided by USGS Priority Ecosystem Studies Program and the Sea Turtle Grants Program. The Sea Turtle Grants Program is funded from proceeds from the sale of the Florida Sea Turtle License Plate. We thank NPS for logistical support, especially T. Gottshall and K. Nimmo, as well as K. Ludwig (USGS) and many others for assistance with fieldwork. Thanks to K. Lear and G. Schwieterman for help with data processing and manuscript revision. Any use of trade, product, or firm names is for descriptive purposes only and does not imply endorsement by the US Government.

\section{LITERATURE CITED}

Alerstam T, Hedenström A, Åkesson S (2003) Long-distance migration: evolution and determinants. Oikos 103: $247-260$
Allard MW, Miyamoto MM, Bjorndal KA, Bolten AB, Bowen $B$ (1994) Support for natal homing in green turtles from mitochondrial DNA sequences. Copeia 1994:34-41

Ault JS, Smith SG, Bohnsack JA, Luo J and others (2008) Fishery-independent monitoring of coral reef fishes, coral reefs, and macro-invertebrates in the Dry Tortugas. In: Sustaining Dry Tortugas National Park coral reef resources, final report 2008. University of Miami, Miami, FL, p 8-34. www.rsmas.miami.edu/asset/media/drytortugas/cruise-report-2008

Ault JS, Smith SG, Bohnsack JA, Luo J and others (2013) Assessing coral reef fish population and community changes in response to marine reserves in the Dry Tortugas, Florida, USA. Fish Res 144:28-37

$>$ Bjorndal KA (1980) Nutrition and grazing behavior of the green turtle Chelonia mydas. Mar Biol 56:147-154

Bjorndal KA (1997) Foraging ecology and nutrition of sea turtles. In: Lutz P, Musick J (eds) The biology of sea turtles. CRC Press, Boca Raton, FL, p 199-231

> Bjorndal KA, Bolten AB, Chaloupka MY (2003) Survival probability estimates for immature green turtles Chelonia mydas in the Bahamas. Mar Ecol Prog Ser 252: 273-281

Blumenthal JM, Austin TJ, Bothwell JB, Broderick AC and others (2009) Diving behavior and movements of juvenile hawksbill turtles Eretmochelys imbricata on a Caribbean coral reef. Coral Reefs 28:55-65

> Blumenthal JM, Austin TJ, Bothwell JB, Broderick AC and others (2010) Life in (and out of) the lagoon: fine-scale movements of green turtles tracked using time-depth recorders. Aquat Biol 9:113-121

Bolten AB (2003) Variation in sea turtle life history patterns: neritic vs. oceanic developmental stages. In: Lutz PL, Musick JA, Wyneken J (eds) The biology of sea turtles, Vol II. CRC Press, Boca Raton, FL, p 243-257

Brill RW, Balazs GH, Holland KN, Chang RKC, Sullivan S, George JC (1995) Daily movements, habitat use, and submergence intervals of normal and tumor-bearing juvenile green turtles (Chelonia mydas L.) within a foraging area in the Hawaiian islands. J Exp Mar Biol Ecol 185:203-218

Brönmark C, Skov C, Brodersen J, Nilsson PA, Hansson L (2008) Seasonal migration determined by a trade-off between predator avoidance and growth. PLOS ONE 3: e1957

Carr AF (1987) New perspectives on the pelagic stage of sea turtle development. Conserv Biol 1:103-121

> Carr A, Meylan AB (1980) Evidence of passive migration of green turtle hatchlings in sargassum. Copeia 1980: 366-368

> Carr A, Ross P, Carr S (1974) Internesting behavior of the green turtle, Chelonia mydas, at a mid-ocean island breeding ground. Copeia 1974:703-706

Carrier JC, Pratt HL (1998) Habitat management and closure of a nurse shark breeding and nursery ground. Fish Res 39:209-213

> Chapman BB, Hulthén K, Blomqvist DR, Hansson L and others (2011) To boldly go: individual differences in boldness influence migratory tendency. Ecol Lett 14:871-876

> Cheng IJ, Bentivegna F, Hochscheid S (2013) The behavioral choices of green turtles nesting at two environmentally different islands in Taiwan. J Exp Mar Biol Ecol 440: 141-148

Ehrhart LM, Ogren LH (1999) Studies in foraging habits capturing and handling turtles. In: Eckert KL, Bjorndal 
KA, Abreu-Grobois FA, Donnelly M (eds) Research and management techniques for the conservation of sea turtles. IUCN/SSC Marine Turtle Specialist Group Publication No. 4., Washington, DC, p 61-65

Enright JT (1977) Diurnal vertical migration: adaptive significance and timing. Part 1 . Selective advantage: a metabolic model. Limnol Oceanogr 22:856-872

> Fossette S, Gleiss AC, Myers AE, Garner S and others (2010) Behaviour and buoyancy regulation in the deepestdiving reptile: the leatherback turtle. J Exp Biol 213: 4074-4083

Francke DL, Hargrove SA, Vetter EW, Winn CD, Balazs GH, Hyrenback KD (2013) Behavior of juvenile green turtles in a coastal neritic habitat: validating time-depthtemperature records using visual observations. J Exp Mar Biol Ecol 444:55-65

> Gleiss AC, Dale JJ, Holland KN, Wilson RP (2010) Accelerating estimates of activity-specific metabolic rate in fish: testing the applicability of acceleration data-loggers. J Exp Mar Biol Ecol 385:85-91

> Godley BJ, Blumenthal JM, Broderick AC, Coyne MS, Godfrey MH, Hawkes LA, Witt MJ (2008) Satellite tracking of sea turtles: Where have we been and where do we go next? Endang Species Res 4:3-22

> Halsey LG, Jones TT, Jones DR, Liebsch N, Booth DT (2011) Measuring energy expenditure in sub-adult and hatchling sea turtles via accelerometry. PLOS ONE 6:e22311

$>$ Hart KM, Fujisaki I (2010) Satellite tracking reveals habitat use by juvenile green sea turtles Chelonia mydas in the Everglades, Florida, USA. Endang Species Res 11: 221-232

> Hart KM, Hyrenbach KD (2009) Satellite telemetry of marine megavertebrates: the coming of age of an experimental science. Endang Species Res 10:9-20

> Hart KM, Zawada DG, Fujisaki I, Lidz BH (2013) Habitat use of breeding green turtles Chelonia mydas tagged in Dry Tortugas National Park: making use of local and regional MPAs. Biol Conserv 161:142-154

Hays GC, Adams CR, Broderick AC, Godley BJ, Lucas DJ, Metcalfe JD, Prior AA (2000) The diving behavior of green turtles at Ascension Island. Anim Behav 59: $577-586$

> Hays GC, Akesson S, Broderick AC, Glen F and others (2001) The diving behaviour of green turtles undertaking oceanic migration to and from Ascension Island: dive durations, dive profiles and depth distribution. J Exp Biol 204:4093-4098

> Hays GC, Metcalfe JD, Walne AW (2004) The implications of lung-regulated buoyancy control for dive depth and duration. Ecology 85:1137-1145

> Hazel J, Hamann M, Lawler IR (2013) Home range of the immature green turtles tracked at an offshore tropical reef using automated passive acoustic telemetry. Mar Biol 160:617-627

> Heithaus MR, Frid A, Dill LM (2002) Shark-inflicted injury frequencies, escape response, and habitat use of green and loggerhead turtles. Mar Biol 140:229-236

Heithaus MR, Frid A, Wirsing AJ, Dill LM and others (2007) State-dependent risk-taking by green sea turtles mediates top-down effects of tiger shark intimidation in a marine ecosystem. J Anim Ecol 76:837-844

Hirth HF (1997) Synopsis of the biological data on the green turtle, Chelonia mydas (Linnaeus 1758). Fish and Wildlife Service biological report 97, US Department of the Interior, Washington, DC
Hochscheid S (2014) Why we mind sea turtles' underwater business: a review on the study of diving behavior. J Exp Mar Biol Ecol 450:118-136

> Hochscheid S, Godley BJ, Broderick AC, Wilson RP (1999) Reptilian diving: highly variable dive patterns in the green turtle Chelonia mydas. Mar Ecol Prog Ser 185: 101-112

Hochscheid S, Bentivegna F, Speakman JR (2003) The dual function of the lung in chelonian sea turtles: buoyancy control and oxygen storage. J Exp Mar Biol Ecol 297: $123-140$

Houghton DR, Broderick AC, Godley BJ, Metcalfe JD, Hays GC (2002) Diving behavior during the internesting interval for loggerhead turtles Caretta caretta nesting in Cyprus. Mar Ecol Prog Ser 227:63-70

Lidz BH, Zawada DG (2013) Possible return of Acropora cervicornis at Pulaski Shoal, Dry Tortugas National Park, Florida. J Coast Res 29:256-271

> MacDonald BD, Madrak SV, Lewison RL, Seminoff JA, Eguchi T (2013) Fine scale diel movement of the east Pacific green turtle, Chelonia mydas, in a highly urbanized foraging environment. J Exp Mar Biol Ecol 443: 56-64

> Makowski C, Seminoff JA, Salmon M (2006) Home range and habitat use of juvenile Atlantic green turtles (Chelonia mydas L.) on shallow reef habitats in Palm Beach, Florida. Mar Biol 148:1167-1179

Mallinson D, Hine A, Hallock P, Locker S and others (2003) Development of small carbonate banks on the south Florida platform margin: response to sea level and climate change. Mar Geol 199:45-63

McClellan CM, Read AJ (2009) Confronting the gauntlet: understanding incidental capture of green turtles through fine-scale movement studies. Endang Species Res 10:165-179

Mendonça MT (1983) Movements and feeding ecology of immature green turtles (Chelonia mydas) in a Florida lagoon. Copeia 1983:1013-1023

Minamikawa S, Naito Y, Uchida I (1997) Bouyancy control in diving behavior of the loggerhead turtle, Caretta caretta. J Ethol 15:109-118

Musick J, Limpus C (1997) Habitat utilization and migration in juvenile sea turtles. In: Lutz P, Musick JA (eds) The biology of sea turtles. CRC Press, Boca Raton, FL, p 137-164

National Park Service (2006) Dry Tortugas National Parkspecial regulations. Fed Regist 71:76154-76166

NMFS \& USFWS (National Marine Fisheries Service \& US Fish and Wildlife Service) (1991) Recovery plan for US population of Atlantic green turtle Chelonia mydas. NMFS, Washington, DC

NMFS-SEFSC (National Marine Fisheries Service Southeast Fisheries Science Center) (2008) Sea turtle research techniques manual. NOAA Tech Memo NMFS-SEFSC579, US Department of Commerce, Washington, DC

> Ogden JC, Robinson L, Whitlock K, Daganhardt H, Cebula R (1983) Diel foraging patterns in juvenile green turtles (Chelonia mydas L.) in St. Croix United States Virgin Islands. J Exp Mar Biol Ecol 66:199-205

Okuyama J, Kawabata Y, Naito Y, Arai N, Kobayashi M (2010) Monitoring beak movements with an acceleration datalogger: a useful technique for assessing the feeding and breathing behaviors of sea turtles. Endang Species Res 10:39-45

Okuyama J, Kataoka K, Kobayashi M, Abe O, Yoseda K, 
Arai N (2012) The regularity of dive performance in sea turtles: a new perspective from precise activity data. Anim Behav 84:349-359

Okuyama J, Nakajima K, Noda T, Kimura S and others (2013) Ethogram of immature green turtles: behavioral strategies for somatic growth in large marine herbivores. PLOS ONE 8:e65783

Okuyama J, Tabata R, Nakajima K, Arai N, Kobayashi M, Kagawa S (2014) Surfacers change their dive tactics depending on the aim of the dive: evidence from simultaneous measurements of breaths and energy expenditure. Proc R Soc Lond B Biol Sci 281:20140040

Pinheiro J, Bates D, DebRoy S, Sarkar D, R Core Team (2014) nlme: linear and nonlinear mixed effects models. $\mathrm{R}$ package version 31-117

Plotkin P (2003) Adult migrations and habitat use. In: Lutz PL, Musick JA, Wyneken J (eds) The biology of sea turtles, Vol II. CRC Press, Boca Raton, FL, p 225-242

R Core Team (2016) R: a language and environment for statistical computing. R Foundation for Statistical Computing, Vienna

Sakamoto KQ, Sato K, Ishizuka M, Watanuki Y, Takahashi A, Daunt F, Wanless S (2009) Can ethograms be automatically generated using body acceleration data from freeranging birds? PLOS ONE 4:e5379

Schmid JR (1998) Marine turtle populations on the westcentral coast of Florida: results of tagging studies at the Cedar Keys, Florida, 1986-1995. Fish Bull 96:589-602

Seminoff JA, Jones TT (2006) Diel movements and activity ranges of green turtles (Chelonia mydas) at a temperate foraging area in the Gulf of California, Mexico. Herpetol Conserv Biol 1:81-86

Seminoff JA, Resendiz A, Nichols WJ (2002) Home range of green turtles Chelonia mydas at a coastal foraging area in the Gulf of California, Mexico. Mar Ecol Prog Ser 242: 253-265

Seminoff JA, Jones TT, Marshall GJ (2006) Underwater behavior of green turtles monitored with video-time-

Editorial responsibility: Bryan Wallace,

Boulder, Colorado, USA depth recorders: What's missing from dive profiles? Mar Ecol Prog Ser 322:269-280

Skov C, Baktoft H, Brodersen J, Brönmark C, Chapman BB, Hansson L, Nilsson PA (2011) Sizing up your enemy: individual predation vulnerability predicts migratory probability. Proc R Soc B 278:1414-1418

> Southwood AL, Reina RD, Jones VS, Jones DR (2003) Seasonal diving patterns and body temperature of juvenile green turtles at Heron Island, Australia. Can J Zool 81: 1014-1024

Taquet C, Taquet M, Dempster T, Soria M, Ciccione S, Roos D, Dagorn L (2006) Foraging of the green sea turtle Chelonia mydas on seagrass beds at Mayotte Island (Indian Ocean), determined by acoustic transmitters. Mar Ecol Prog Ser 306:295-302

Thomson JA, Heithaus MR, Dill LM (2011) Informing the interpretation of dive profiles using animal-borne video: a marine turtle case study. J Exp Mar Biol Ecol 410:12-20

> van Dam RP, Diez CE (1996) Diving behavior of immature hawksbills (Eretmochelys imbricata) in a Caribbean cliffwall habitat. Mar Biol 127:171-178

- Werner EE, Gilliam JF (1984) The ontogenetic niche and species interactions in size-structured populations. Annu Rev Ecol Syst 15:393-425

Williams SL (1988) Thalassia testudinum productivity and grazing by green turtles in a highly disturbed seagrass bed. Mar Biol 98:447-455

Wilson RP, Shepard ELC, Liebsch N (2008) Prying into the intimate details of animal lives: use of a daily diary on animals. Endang Species Res 4:123-137

> Yasuda T, Arai N (2009) Changes in flipper beat frequency, body angle and swimming speed of female green turtles Chelonia mydas. Mar Ecol Prog Ser 386:275-286

Zawada DG, Hart KM (2010) Detailed seafloor habitat mapping to enhance marine-resource management. US Geological Survey Fact Sheet 2010-3090, US Geological Survey, Reston, VA

Submitted: February 1, 2016; Accepted: July 19, 2016

Proofs received from author(s): September 12, 2016 